\title{
마르키아파바-비냐미병에서 학산텐서영상
}

\author{
이재원 유봉구 \\ 고신대학교복음병원 신경과
}

\section{Diffusion Tensor Imaging in Marchiafava-Bignami Disease}

\author{
Jae Won Lee, MD, Bong-Goo Yoo, MD \\ Depratment of Neurology, Kosin University Gospel Hospital, Busan, Korea
}

J Korean Neurol Assoc 38(3):237-238, 2020

32세 남자가 서서히 악화된 의식 저하와 섬망으로 왔다. 수년 전부터 알코올중독이며, 2개월 전부터 거의 침상에서 지냈다. 뇌 자기공명영상의 확산강조영상과 액체감쇠역전회복영상에서 뇌들 보(corpus callosum)와 이마관자엽의 피질과 피질하에 다발성 고신 호강도가 관찰되었다(Fig. 1). 확산텐서영상(diffusion tensor imaging)과 신경섬유경로영상(fiber tractography)에서 뇌들보를 통한 맞 교차섬유(commissural fibers) 소실과 분획비등방성(fractional anisotropy)의 감소가 관찰되었다(Fig. 2-A, B). 비타민B복합제와 스테 로이드를 사용하였고, 의식과 전반적인 상태가 점차 호전되었다. 입원 39일에 추적 확산텐서영상에서는 뇌들보의 회복과 분획비등방 성의 증가가 있었다(Fig. 2-C, D).

마르키아파바-비냐미병에서 확산텐서영상은 병의 진단, 정도 및
예후 평가에 유용하다. ${ }^{1}$ 분획비등방성은 백질의 물 분자 이동으로 백질의 구조적 연결 정도를 평가하며 숫자로 나타난다. ${ }^{2}$ 본 증례는 확산텐서영상을 이용하여 신경 손상과 회복을 확인할 수 있었고, 이런 영상은 뇌들보 같은 백질 평가에 유용하다.

\section{REFERENCES}

1. Sair HI, Mohamed FB, Patel S, Kanamalla US, Hershey B, Hakma Z, et al. Diffusion tensor imaging and fiber-tracking in Marchiafava-Bignami disease. J Neuroimaging 2006;16:281-285.

2. Filippi CG, Cauley KA. Lesions of the corpus callosum and other commissural fibers: diffusion tensor studies. Semin Ultrasound CT MR 2014;35:454-458.

Received January 29, 2020 Revised April 1, 2020

Accepted April 1, 2020

Address for comespondence: Bong-Goo Yoo, MD

Depratment of Neurology, Kosin University Gospel Hospital, 262

Gamcheon-ro, Seo-gu, Busan 49267, Korea

Tel: +82-51-990-6461 Fax: +82-51-990-3077

E-mail: ybg99@naver.com 

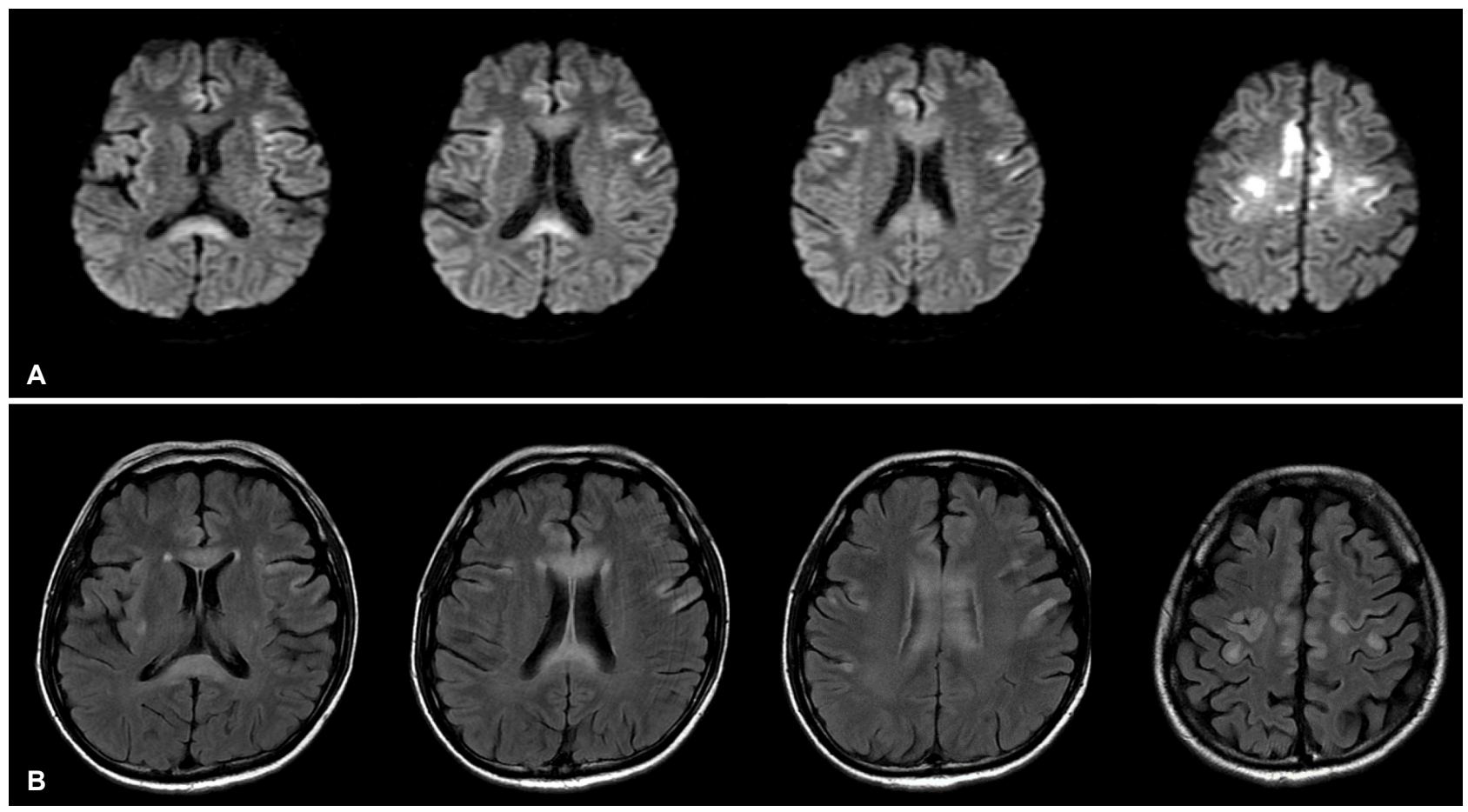

Figure 1. Brain magnetic resonance imaging of the patient. Axial diffusion-weighted (A) and fluid-attenuated inversion recovery (B) images show multiple hyperintense lesions in the corpus callosum and bilateral frontotemporal cortical and subcortical areas.
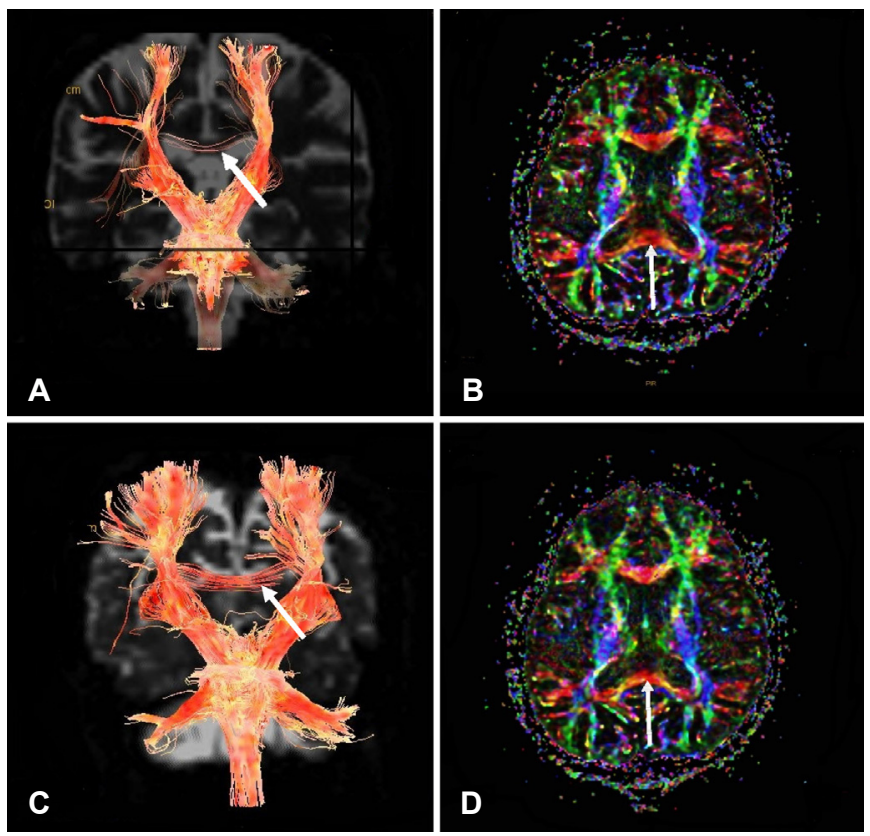

Figure 2. Serial diffusion tensor image (DTI) of the patient. Initial tractography reveals thinning (arrow) of the corpus callosum (A). Follow-up tractography demonstrates visually thickening (arrow) of the corpus callosum (C). Initial fractional anisotropy (FA) value (B) of the corpus callosum (arrow) is 0.545 , follow-up FA (D) is 0.587 . 